\title{
SEED PREDATION IN WILD POPULATIONS OF CHAMISSO ARNICA (ARNICA CHAMISSONIS LESS: ASTERACEAE) AND NEW HOST RECORDS FOR CAMPIGLOSSA SNOWI (HERING) (DIPTERA: TEPHRITIDAE)
}

\author{
Robert L. Johnson 1,3 , Val J. Anderson², Adam T. Yankee1, and Zachary Anderson²
}

\begin{abstract}
New host records are reported for Campiglossa snowi (Hering), Tephritis leavittensis Blanc, and Trupanea nigricornis (Coquillett) on Arnica chamissonis Less. and C. snowi on Arnica mollis Hook. Campiglossa snowi was the only fruit fly reared from A. chamissonis from 3 different populations from the Kenai Peninsula, Alaska, over 5 sample years. A total of 1114 specimens of C. snowi were reared from the flower heads of 337 plants averaging 5 flower heads per plant. Seed damage from fly larvae ranged from $0 \%$ to $54.8 \%$ per capitulum, with an overall average of $18.3 \%$ across all years and between 3 sites on the Kenai Peninsula. Infestation rates for individual capitula and entire plants averaged $56.4 \%$ and $79.0 \%$, respectively, across all years and sites. Fly abundance was not consistent from year to year, but peaked during 2010, with substantially lower values in years preceding and following the peak. Campiglossa snowi individuals reared from flower heads at additional sites and across multiple states expand the species' known distribution range.
\end{abstract}

Resumen.-Reportamos nuevos registros de huéspedes de la flor Arnica chamissonis Less: Campiglossa snowi (Hering), Tephritis leavittensis Blanc y Trupanea nigricornis (Coquillett), y C. snowi de la flor Arnica mollis Hook. Campiglossa snowi fue la única mosca de que se desarrolló en A. chamissonis en 3 poblaciones diferentes de la Península de Kenai, Alaska, durante 5 años de muestreo. Durante este tiempo, un total de 1,114 ejemplares de C. snowi crecieron en la cabeza de las flores de 337 plantas con un promedio de 5 cabezas por planta. El daño causado en las semillas debido a las larvas de mosca osciló entre $0 \%-54.8 \%$ por capítulo, con un promedio total de $18.3 \%$ a lo largo de todos los años de muestreo y entre 3 sitios en la península de Kenai. Las tasas de infestación de capítulos individuales y de plantas enteras mostraron un promedio de entre $56.4 \%$ y $79.0 \%$ a lo largo de todos los años y sitios respectivamente. La abundancia de moscas no fue consistente de un año a otro, pero alcanzó su máximo durante el 2010 con valores sustancialmente más bajos en los años anteriores y posteriores. Campiglossa snowi que se desarrolló en la cabeza de las flores en sitios adicionales y a lo largo de múltiples estados muestra una expansión de su rango de distribución conocido.

Plant host relationships of fruit flies (Diptera: Tephritidae) have worldwide research interest primarily due to economic impacts of tephritid flies on major fruit and vegetable crops (Badii et al. 2015, Walton et al. 2016). Nonfrugivorous fruit flies are also routinely studied for biological control opportunities against invasive weeds (Pitcairn et al. 2008, Skuhrovec et al. 2008, Story et al. 2008, Birdsall and Markin 2010).

Most seed-feeding fruit flies parasitize plants in the family Asteraceae (Foote et al. 1993) where flowers are arranged in a compact flower head (capitulum) and fly larvae are able to move throughout the flower head to feed on multiple seeds and flower parts (Headrick and Goeden 1998). Plants that have commercial value in the harvesting of seed or flower heads can be negatively impacted by seed predators.
This study investigates seed predation by tephritid fruit flies in wild populations of chamisso arnica (Arnica chamissonis Less., Asteraceae). There are 2 major potential uses of $A$. chamissonis for which seed predation may pose a concern: as a seed crop for the reclamation industry or as a pharmaceutical crop. Because of the increased interest in seed harvest from wild populations of native plants (Lippitt et al. 1994, Vander Mijnsbrugge et al. 2010, Broadhurst et al. 2015) and commercial cultivation of native plants for the reclamation industry (Shaw et al. 2005, 2012, Mock et al. 2016), the impact of fruit flies that parasitize seeds, thus affecting seed production, poses potential risks. Arnica chamissonis was included in the inventory of species deposited at the Royal Botanic Gardens, Kew, Millennium Seed Bank under the Bureau of Land Management's Seeds of Success program

\footnotetext{
${ }^{1}$ Department of Biology, Brigham Young University, Provo, UT 84602.

${ }^{2}$ Department of Plant and Wildlife Sciences, Brigham Young University, Provo, UT 84602.

${ }^{3} \mathrm{E}$-mail: robert_johnson@byu.edu
} 
(De Bolt and Spurrier 2004) to "collect, conserve, and develop native plant material for stabilizing, rehabilitating, and restoring lands in the United States" (BLM 2016). Part of what makes A. chamissonis an attractive restoration species is its ability to colonize disturbed roadsides where its showy yellow flowers contribute to an aesthetically pleasing roadside landscape. Use of A. chamissonis as a reclamation species is still limited, however, primarily because it grows in areas where reclamation needs are as yet minimal.

Arnica also has potential as a pharmaceutical crop. Several Arnica species, including A. chamissonis, have been identified for pharmaceutical research where flavonoids and other compounds are harvested from the flower heads (Cassells et al. 1999, Roki et al. 2001, Saeed 2014). Extracts from these plants have recently been identified as having potential value in treating Alzheimer's disease (Russo et al. 2013), and the seeds possess a wide array of antioxidant compounds (Gawlik-Dziki et al. 2009). In order to reduce harvesting pressures on wild plants, researchers have recommended growing Arnica and other pharmaceutical plants under cultivation (Schippmann et al. 2002, Sugier et al. 2013). Knowledge of plant pests that can potentially reduce pharmaceutical yields could be important, especially when plants are grown as a monoculture.

In addition to the value of studying seed predation in A. chamissonis for reasons of commercial application, it is valuable to document the occurrence and extent of seed predation by a tephritid fruit fly on a plant with little host association information. Much of the information on nonfrugivorous tephritid host associations is no more than the association record, with information seldom provided on the extent of seed damage (Foote et al. 1993).

Arnica chamissonis is an attractive plant with yellow petals in the family Asteraceae found throughout most of western North America (Wolf 2006). It ranges from Alaska south to California and as far east as Quebec, Canada, though records of its eastern range in the United States terminate in Montana and south through Wyoming, Colorado, and New Mexico, with a recorded presence in Oklahoma (USDA-NRCS 2015) (Fig. 1). We agree with and follow the taxonomic treatment of A. chamissonis by Wolf (2006) in Flora of North America and Wolf and Barkley (2012) in The Jepson Manual. In their treatments, all varieties or subspecies are synonymized under the nominate A. chamissonis sensu lato. The degree of variation, primarily of leaf and stem pubescence, intergrades between geographical regions, making it difficult to segregate published varieties with confidence. Even determinations between recognized species can be difficult, especially when smaller specimens lack the distinguishing number of leaves per stem used in modern taxonomic keys. It is important to recognize, however, that different genotypes likely exist across the broad distribution of A. chamissonis, particularly if the species is used for restoration and site-adapted genotypes are desired.

While visiting Alaska during summer 2013, the authors discovered a tephritid fruit fly while sweep-netting A. chamissonis on the Kenai Peninsula where populations of plants are regularly encountered growing roadside. After an initial interest in recording the host association, we hypothesized that the presence of seedpredating tephritid fruit flies would have a negative impact on seed yield in A. chamissonis populations. To test this assumption, we sampled flower heads of A. chamissonis across several sites and years on the Kenai Peninsula, Alaska. We also report additional host associations of tephritid fruit flies on Arnica spp. from elsewhere in the western United States.

\section{Methods}

Flower heads of A. chamissonis were collected in 2007, 2009, 2010, 2011, and 2013 from 3 sites on the Kenai Peninsula, Alaska. These sites were chosen during the first reconnaissance year upon encountering an adequate plant population size within the time constraints of travel. The 3 selected study sites were roadside populations in the vicinity of Seward, Alaska, and were between $200 \mathrm{~m}^{2}$ and $500 \mathrm{~m}^{2}$ in population area, but with estimated population sizes of $>1000$ plants. Site locations were Seward Tracks (60.12611, -149.43485, 21 m elevation), Salmon River (60.18186, - 149.3903, $58 \mathrm{~m}$ elevation), and Nash Road $(60.13264,-149.37935,17$ m elevation). Flower heads were collected on the following dates: 17 August 2007, 24 July 2009, 23 July 2010, 22 July 2011, and 25 July 2013. A minimum of 20 plants were randomly selected from each plant population using a 


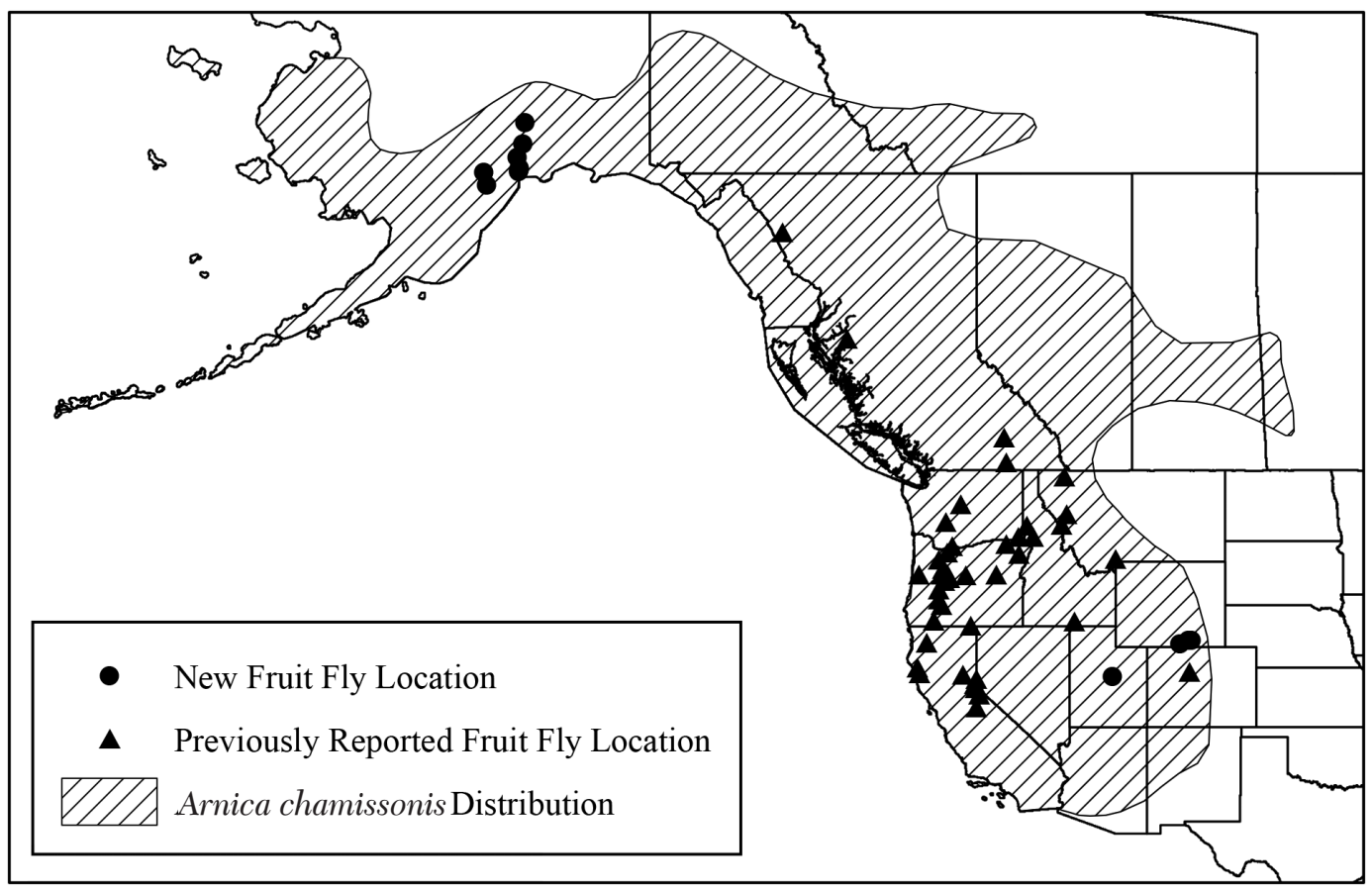

Fig. 1. Distribution of Campiglossa snowi and its host plant Arnica chamissonis. The distribution of A. chamissonis in North America was determined by georeferenced specimens from online herbarium databases (CMN [2014], ABMI [2015], SEINet [2009-2015], PNWH [2015]). There were also a few isolated and unconfirmed occurrences of the species in western Canada, which were not included in this figure. New C. snowi locations were documented by our own field research; previously known locations were documented by Richard H. Foote (Foote and Blanc 1963, Foote et al. 1993).

nearest-neighbor-to-transect-point method, with the transect(s) bisecting the population and the 20 transect points evenly distributed. All flower heads were collected at mid to late anthesis. The presence of fly pupa was confirmed by opening capitula to reveal black puparia. For the occasional flies that emerged prior to flower head collection, puparia still remained in the flower heads and was used for tallying. All flower heads from each sampled plant were sealed in a plastic bag and stored in a cooler for transport to the lab for rearing. Flower heads were then placed in plastic 4ounce $(120-\mathrm{mL})$ portion cups with perforated lids for rearing with ambient air temperatures ranging between a nighttime low of $65{ }^{\circ} \mathrm{F}$ $\left(18.3^{\circ} \mathrm{C}\right)$ and a daytime high of $80^{\circ} \mathrm{F}\left(26.7^{\circ} \mathrm{C}\right)$. Flower heads were left in their rearing cups for 2 months. Emerged flies were then identified and tallied.

The percent seed damage was estimated for each seed head by examining the seeds under a dissecting microscope to determine damaged versus undamaged seeds. Each flower head was opened and each seed examined. Seeds that showed larval feeding that penetrated the seed coat were counted as damaged.

Additional collections of A. chamissonis flower heads were made within the states of Alaska, Oregon, Wyoming, and Utah in 2013 and 2014 and reared in plastic portion cups (Table 1, Fig. 1). These additional collections were made from several road trips to locations identified from herbarium specimens as locations for A. chamissonis. This effort was designed to get a better picture of the distribution of tephritid host associations in areas with few association records where A. chamissonis occurs. These additional locations were not "study sites," as are the 3 sites from the Kenai Peninsula, but instead were sites where flower heads were collected during only a single visit. The additional survey sites were not part of the analysis of seed predation over time, but represent host association records verified through rearing trials. The following are coordinates of other sampled Arnica species: A. cordifolia (Utah, Daggett Co., Uinta 
TABLE 1. Plant sample characteristics of Arnica chamissonis and rearing results for Campiglossa snowi from those samples taken from survey sites at the Kenai Peninsula, Alaska.

\begin{tabular}{|c|c|c|c|c|}
\hline \multirow[b]{2}{*}{ Metric } & \multirow[b]{2}{*}{ Year } & \multicolumn{3}{|c|}{ Study sites } \\
\hline & & Seward Tracks & Salmon River & Nash Road \\
\hline Number of plants sampled & $\begin{array}{l}2007 \\
2009 \\
2010 \\
2011 \\
2013\end{array}$ & $\begin{array}{l}34 \\
20 \\
20 \\
21 \\
20\end{array}$ & $\begin{array}{l}26 \\
20 \\
20 \\
20 \\
21\end{array}$ & $\begin{array}{l}34 \\
21 \\
20 \\
20 \\
20\end{array}$ \\
\hline Total seed production per 20 plants & $\begin{array}{l}2007 \\
2009 \\
2010 \\
2011 \\
2013\end{array}$ & $\begin{array}{r}19,099 \\
6381 \\
5358 \\
4503 \\
6021\end{array}$ & $\begin{array}{r}16,417 \\
6447 \\
5671 \\
3161 \\
8330\end{array}$ & $\begin{array}{r}10,140 \\
7324 \\
4716 \\
4007 \\
6800\end{array}$ \\
\hline Min-max seeds per capitulum & $\begin{array}{l}2007 \\
2009 \\
2010 \\
2011 \\
2013\end{array}$ & $\begin{array}{l}54-192 \\
46-119 \\
41-142 \\
52-117 \\
37-107\end{array}$ & $\begin{array}{l}52-131 \\
53-126 \\
42-121 \\
41-114 \\
50-115\end{array}$ & $\begin{array}{l}45-159 \\
34-142 \\
47-112 \\
52-142 \\
48-144\end{array}$ \\
\hline Average seed per capitulum & $\begin{array}{l}2007 \\
2009 \\
2010 \\
2011 \\
2013\end{array}$ & $\begin{array}{r}105.5 \\
88.6 \\
90.8 \\
84.1 \\
78.2\end{array}$ & $\begin{array}{l}86.9 \\
80.6 \\
79.9 \\
64.4 \\
78.1\end{array}$ & $\begin{array}{l}85.9 \\
90.2 \\
84.2 \\
81.8 \\
86.1\end{array}$ \\
\hline Average $\%$ seed damaged & $\begin{array}{l}2007 \\
2009 \\
2010 \\
2011 \\
2013\end{array}$ & $\begin{array}{r}8.3 \\
12.6 \\
28.9 \\
7.1 \\
0.0\end{array}$ & $\begin{array}{r}10.0 \\
20.0 \\
31.9 \\
18.8 \\
5.3\end{array}$ & \begin{tabular}{r|}
17.6 \\
28.8 \\
54.8 \\
13.9 \\
3.3
\end{tabular} \\
\hline Average $\%$ capitulum infestation & $\begin{array}{l}2007 \\
2009 \\
2010 \\
2011 \\
2013\end{array}$ & $\begin{array}{r}29.2 \\
54.2 \\
89.8 \\
19.6 \\
0.0\end{array}$ & $\begin{array}{l}39.7 \\
61.3 \\
84.5 \\
89.4 \\
32.7\end{array}$ & $\begin{array}{l}58.5 \\
90.1 \\
96.4 \\
69.4 \\
31.6\end{array}$ \\
\hline$\%$ Plant infestation & $\begin{array}{l}2007 \\
2009 \\
2010 \\
2011 \\
2013\end{array}$ & $\begin{array}{r}52.9 \\
85.0 \\
100.0 \\
30.0 \\
0.0\end{array}$ & $\begin{array}{r}84.6 \\
85.0 \\
100.0 \\
94.4 \\
95.2\end{array}$ & $\begin{array}{r}97.1 \\
100.0 \\
100.0 \\
90.0 \\
71.4\end{array}$ \\
\hline Total reared C. snowi & $\begin{array}{l}2007 \\
2009 \\
2010 \\
2011 \\
2013\end{array}$ & $\begin{array}{r}33 \\
48 \\
93 \\
16 \\
0\end{array}$ & $\begin{array}{r}89 \\
89 \\
128 \\
130 \\
45\end{array}$ & $\begin{array}{r}77 \\
116 \\
165 \\
43 \\
42\end{array}$ \\
\hline
\end{tabular}

Mtns., 40.83796, -110.00060, $3106 \mathrm{~m}$ elevation, 5 August 2013) and A. mollis Hook. (Utah, Sanpete Co., Fairview Cyn., 39.57096, -111.30891, 3038 m elevation, 20 July 2013; Wyoming, Albany Co., Medicine Bow Mtn., 41.35332, - 106.24796, $3245 \mathrm{~m}$ elevation, 9 August 2013; Oregon, Grant Co., nr Indian Peak, 44.75604, -118.71664, $1901 \mathrm{~m}$ elevation, 30 July 2014; Oregon, Hood River Co., Dufur Mill Rd., 45.39474, -121.5001, 1399 m elevation, 31 July 2014).

Pinned voucher specimens of tephritids were deposited in the insect collection
(BYUC) at the Monte L. Bean Museum, Brigham Young University, Provo, Utah. Voucher specimens of A. chamissonis were deposited in the Stanley L. Welsh Herbarium (BRY) in the aforementioned museum. Plant vouchers have been databased and are accessible through the Southwest Environmental Information Network (SEINet 2009-2015) with the following herbarium catalog numbers: A. chamissonis: BRY41284, BRY41291, BRY41931, BRY40049, BRY40048, BRY47663, BRY114890, BRY38634, BRY32445; A. mollis: BRY41932, BRY622181, BRY622185, BRY 
TABLE 2. Emergence of tephritid fly species from Arnica chamissonis locations additional to the 3 primary study sites.

\begin{tabular}{|c|c|c|c|c|}
\hline Site & Coordinates & Elevation $(\mathrm{m})$ & $\begin{array}{l}\text { Specimens } \\
\text { reared }\end{array}$ & Species reared \\
\hline AK, Anchorage, Girdwood & $60.94577,-149.16904$ & 29 & 3 & Campiglossa snowi \\
\hline $\begin{array}{l}\text { AK, Kenai Peninsula, Lowell } \\
\text { Point }\end{array}$ & $60.07039,-149.44212$ & 10 & 8 & Campiglossa snowi \\
\hline AK, Kenai Peninsula, Homer & $59.63972,-151.50459$ & 3 & 3 & Campiglossa snowi \\
\hline AK, Kenai Peninsula, Tern Lake & $60.53487,-149.54280$ & 180 & 1 & Campiglossa snowi \\
\hline AK, Kenai Peninsula, Ninilchik & $60.03962,-151.67183$ & 37 & 1 & Campiglossa snowi \\
\hline AK, Matanuska-Susitina, Palmer & $61.61391,-149.05296$ & 134 & 2 & Campiglossa snowi \\
\hline WY, Park Co., Pelican Crk. & $44.55653,-110.36163$ & 2362 & 11 & Trupanea jonesii \\
\hline $\begin{array}{l}\text { OR, Clackamas Co., Clackamas } \\
\text { Lake }\end{array}$ & $45.10080,-121.74295$ & 1040 & 1 & Campiglossa snowi \\
\hline OR, Lake Co., Paulina Marsh & $43.17627,-121.03632$ & 1310 & 84 & Trupanea jonesii \\
\hline OR, Lake Co., Paulina Marsh & $43.17627,-121.03632$ & 1310 & 14 & $\begin{array}{l}\text { Euarestiodes } \\
\text { acutangulis }\end{array}$ \\
\hline OR, Lake Co., Paulina Marsh & $43.17627,-121.03632$ & 1310 & 13 & Tephritis leavittensis \\
\hline UT, Daggett Co., Uinta Mtns. & $40.87836,-109.96466$ & 2890 & 77 & Trupanea jonesii \\
\hline UT, Daggett Co., Uinta Mtns. & $40.87836,-109.96466$ & 2890 & 20 & Tephritis leavittensis \\
\hline UT, Daggett Co., Uinta Mtns. & $40.87836,-109.96466$ & 2890 & 3 & Trupanea nigricornis \\
\hline
\end{tabular}

73170, BRY120510, BRY114886; A. cordifolia: BRY38653.

\section{RESUlTS}

Between the 3 study sites on the Kenai Peninsula (2007-2011), capitula per plant varied from 3 to 9 . Though not measured for height, plants in 2007 were observably larger than in subsequent years when the average number of flower heads was 4 per plant. The lowest average number of capitula per plant occurred in 2011 at 3 per plant across all sites. Seed production per capitulum ranged from 37 to 192 seeds with an overall average of 84 seeds across all 3 Kenai study sites and years (Table 1).

Though flower heads of A. chamissonis remained in plastic cups for 2 months, all flies emerged within 2 weeks of flower heads being placed in cups. The fruit fly Campiglossa snowi was the only fly species to emerge from the Alaska Arnica populations. This is the first host record for $C$. snowi with A. chamissonis and is the first published record of C. snowi occurring in Alaska, establishing a new northern range extension for C. snowi (Fig. 1). The only other insect that emerged from the Alaska sites was a metallic green parasitoid wasp in the genus Pteromalus (Pteromalidae, Hymenoptera). This wasp is a parasitoid of C. snowi and occurred in low numbers relative to the 1114 flies reared.

Capitulum infestation and seed damage varied by year at the 3 Kenai sites, with an apparent peak occurring in the year 2010
(Table 1). In 2013, average percent seed damage dropped below $6.0 \%$ at all sites, with no infestation occurring at the Seward Tracks site (Table 1). As would be expected, reared fly abundance mimicked infestation rates. Fly abundance and infestation rates gradually increased over several years, then were followed by a precipitous decline over several years. The average number of seed damaged per fly larvae from the Kenai Peninsula sites ranged from 7 to 18 seeds across all years and sites with an average of 12 (Table 1).

Flower heads of A. chamissonis collected and reared from locations other than our 3 primary study sites had mixed results of emerging taxa (Table 2). Additional sites from Alaska yielded only C. snowi. The only other investigated site exhibiting the host relationship between A. chamissonis and C. snowi was in Oregon at Mount Hood, the fly's type locality. Several other species of Tephritidae were reared from flower heads of A. chamissonis outside of Alaska (Table 2). Trupanea jonesii (Curran) was reared from A. chamissonis from Wyoming, Oregon, and Utah sites. Trupanea nigricornis (Coquillett) was reared from a Utah site, Tephritis leavittensis Blanc was reared from both an Oregon site and a Utah site, and Euarestoides acutangulus (Thomson) was reared from an Oregon site. It should be noted that specimens of C. snowi were reared from the flower heads of both A. cordifolia and A. mollis from locations in Utah, Wyoming, and Oregon. 


\section{Discussion}

Flower head production and seed yield varied greatly among years. Those differences are likely due to annual changes in environmental factors. Providing uniform nutrient and water resources to wild species under agricultural production systems could help mediate those differences, and agriculture models have been investigated for A. chamissonis (Cassells et al. 1999, Sugier 2007).

Host associations between A. chamissonis and tephritids have interesting biogeographical trends. The plant seems to only host $C$. snowi in its northern clime, particularly in Alaska where few other populations of suitable plants from Asteraceae are blooming concurrently and within proximity. The tephritid C. snowi occurs from California north to British Columbia, with additional records from Idaho, western Montana, and a single record from Colorado (Foote et al. 1993). The larvae of several species in the genus Campiglossa Rondani are known to feed on the developing seeds of Arnica, but nothing has previously been recorded from $A$. chamissonis. Previously, the only known Arnica host association for C. snowi was from Arnica cordifolia Hook. (Foote et al. 1993). The fruit fly Trypeta flaveola (Coquillett) has been reared from $A$. chamissonis, but it is a leaf miner rather than a seed predator (Frick 1971, Han and Norrbom 2005). We expect that C. snowi occurs across the entire range of $A$. chamissonis and will eventually be verified through future tephritid collections. Why other polyphagous tephritids were not reared from Arnica in Alaska is uncertain, but may have more to do with the biology of C. snowi and its ability to adapt to northern climates than with variations occurring between northern and southern genotypes of A. chamissonis. Polyphagous tephritids are able to utilize multiple plant species, and it would be unlikely that a specific Arnica genotype would deter them.

It is unusual that no other tephritid species was reared from the seed heads of 337 plants collected from the Kenai Peninsula of Alaska across 5 sample years spanning a 7-year period. This can partially be explained by the fact that Alaska falls outside the range of the common seed predators T. nigricornis and T. leavittensis (Foote et al. 1993). However, T. jonesii likely occurs in British Columbia, Canada, because it is found in northern Washington, and E. acutangulus has been recorded from Alberta and northern Saskatchewan (Foote et al. 1993). Both of these species are seed predators of A. chamissonis. Neaspilota viridescens Quisenberry occurs in Alaska and is known to feed on many different genera within Asteraceae (Foote et al. 1993) but was not reared from A. chamissonis. Campiglossa albiceps (Loew) occurs in Alaska and feeds on Aster spp., as does Campiglossa dupla (Cresson) on Erigeron; Campiglossa clathrata (Loew) on Haplopappus and Senecio; Campiglossa farinata (Novak) and Campiglossa footeorum (Novak) on A. cordifolia, A. latifolia, and A. rydbergii Greene; Campiglossa genalis (Thomson) on several genera; and Campiglossa murina (Doane) on Haplopappus (Foote et al. 1993).

A. chamissonis hosts at least 4 other tephritid species (some newly reported in this paper) across the more central part of the range. This is the first host record from a rearing trial for T. leavittensis on A. chamissonis, previously only thought to have a relationship with Arnica diversifolia Greene based on sweep net samples (Foote et al. 1993). This is also the first host record for $T$. nigricornis. Both T. jonesii and E. acutangulus have previously been reared from A. chamissonis (Wasbauer 1972). The genera Trupanea and Euarestoides are known to be polyphagous on many genera and species, but exclusive to Asteraceae. Foote et al. (1993) list 75 genera of plant hosts for Trupanea and 9 genera of plant hosts for Euarestoides, so it is not surprising to find them also on A. chamissonis.

Previous host records for C. snowi were limited to A. cordifolia (Foote et al. 1993) and Senecio triangularis Hook. (Novak 1974, Turner and McEvoy 1995). With the addition of A. mollis as a host in this paper, it is likely that most Arnica species can host C. snowi. The degree to which it feeds on the genus Senecio beyond the reported S. triangularis remains unknown, but the fly may not be as host specific as current records indicate. Senecio L. is a large genus with over 55 species recorded for North America (Barkley 2002) and an additional 64 former congeners now in the closely related genus Packera A. Love \& D. Love (Trock 2002). Numerous seed heads from Senecio, including S. triangularis, were collected from the Oregon A. chamissonis sites where we successfully reared C. snowi from the Arnica, but not from Senecio triangularis or S. jacobaea L. 
Though there was site-to-site variation within the Kenai Peninsula sites, the trends in seed damage from year to year showed synchronized increases and declines in fly abundance. The seed of an individual capitulum were never completely consumed, with the highest average damage per capitulum $(54.8 \%)$ occurring at the Nash Road site in 2010 (Table 1). In contrast, Diehl and McEvoy (1989) reported that sometimes capitula of $S$. triangularis would be entirely consumed by C. snowi. Compared to studies of fly damage in other composites (Johnson 2008), the number of A. chamissonis seeds damaged per fly may be high in comparison. It appears that the larvae of this species are highly mobile and feed throughout the flower head, damaging numerous seeds while consuming few. Capitulum damage, while primarily associated with developing seed, was not always the case. In some rare instances, larvae fed on and pupated within the floral parts above the seed, leaving the ovules and seed undamaged. This phenomenon, however, is not typical among seed-feeding tephritids (Headrick and Goeden 1998).

\section{Conclusion}

It is clear that $A$. chamissonis hosts a number of seed predators and that C. snowi has an affinity for multiple species of Arnica. Considering the potential value of $A$. chamissonis for roadside reclamation and pharmaceutical use, seed pest management is warranted. As is often the case, native species of wild-collected seed contribute a significant portion toward seed availability for the industry. While reducing fruit fly pests in wild populations of Arnica is not practical, it could greatly increase seed yields for plants brought under cultivation. The agricultural production of seeds for the reclamation industry and the harvesting of seed heads for the pharmaceutical industry would both benefit from programs that manage seedpredating fruit flies.

\section{ACKNOWLEDGMENTS}

We acknowledge the Stanley L. Welsh Herbarium (BRY) for access to specimens of Arnica and Martina Yankee for constructing the species distribution map (Fig. 1).

\section{Literature Cited}

[ABMi] Alberta Biodiversity Monitoring Institute. 2014. Arnica chamissonis (leafy arnica) - distribution maps. [Accessed 30 January 2015]. http://www .abmi.ca.

Badi, K.B., M.K. Billah, K. Afreh-Nuamah, D. ObengOfori, and G. Nyarko. 2015. Review of the pest status, economic impact and management of fruitinfesting flies (Diptera: Tephritidae) in Africa. African Journal of Agricultural Research 10:1488-1498.

BARKLEY, T.M. 2002. Senecio. In: Flora of North America Editorial Committee, editors. 1993+. Flora of North America North of Mexico. 20+ volumes. New York and Oxford. Volume 20, pages 544-570.

Birdsall, J.L., AND G.P. Markin. 2010. Biological control of yellow starthistle (Centaurea solstitialis) in the Salmon River canyon of Idaho. Invasive Plant Science and Management 3:462-469.

Broadhurst, L., T. Hopley, L. Li, ANd Y.J. Begley. 2015. Using seed production areas to meet restoration targets and secure genetic diversity. Australasian Plant Conservation: Journal of the Australian Network for Plant Conservation 23:7-8.

[BLM] Bureau of Land Management. 2016. Seeds of Success. [Accessed 27 September 2016]. http://www .blm.gov/mt/st/en/prog/botany/sos.html

[CMn] Canadian Museum of Nature. 2015. Research \& Collections search engine. Ottowa, Ontario, Canada; [accessed 30 January 2015]. http://nature.ca/ collections-online

Cassells, A.C., C. Walsh, M. Belin, M. Cambornac, J.R. Robins, and C. Lubrano. 1999. Establishment of a plantation from micropropagated Arnica chamissonis a pharmaceutical substitute for the endangered A. montana. Plant Cell, Tissue and Organ Culture 56:139-144.

De Bolt, A., AND C.S. Spurrier. 2004. Seeds of Success and the Millennium Seed Bank Project. USDA Forest Service Proceedings RMRS-P-31.

DienL, J.W., AND P.B. MCEvoy. 1989. Impact of the cinnabar moth (Tyria jacobaeae) on Senecio triangularis, a non-target native plant of Oregon. Pages 119-126 in E.S. Delfosse, editor, Proceedings, 7th International Symposium on Biological Control of Weeds, Rome. CSIRO, Victoria, Australia.

Foote, R.H., and F.L. Blanc. 1963. The fruit flies or Tephritidae of California. University of California Press, Los Angeles, CA.

Foote, R.H., F.L. Blanc, AND A.L. NoRRBom. 1993. Handbook of the fruit flies (Diptera: Tephritidae) of America North of Mexico. Cornell University Press, Ithaca, NY.

FrICK, K.E. 1971. The biology of Trypeta angustigena Foote in central coastal California - host plants and notes (Diptera: Tephritidae). Journal of the Washington Academy of Science 61:20-24.

GaWlik-Dziki, U., M. Świeca, D. Sugier, and J. CichocKa. 2009. Seeds of Arnica montana and Arnica chamissonis as a potential source of natural antioxidants. Herba Polonica 55:60-71.

HaN, H.Y., AND A.L. NORRBOM. 2005. A systematic revision of the new world species of Trypeta Meigen (Diptera: Tephritidae). Systematic Entomology 30:208-247.

Headrick, D.H., and R.D. Goeden. 1998. The biology of nonfugivorous tephritid fruit flies. Annual Review of Entomology 43:217-241. 
Johnson, R.L. 2008. Impacts of habitat alterations and predispersal seed predation on the reproductive success of Great Basin forbs. Doctoral dissertation, Brigham Young University, Provo, UT.

LippitT, L., M.W. Fidelibus, and D.A. Bainbridge. 1994. Native seed collection, processing and storage for revegetation projects in the western United States. Restoration Ecology 2:120-131.

Mock, B., K. Hansen, R. Coupal, and D. Menkhaus. 2016. Policy experiments for the U.S. Intermountain West native seed industry. Canadian Journal of Agricultural Economics 64:695-716.

NovaK, J.A. 1974. A taxonomic revision of Dioxyna and Paroxyna (Diptera: Tephritidae) for America north of Mexico. Melanderia 16:1-42.

[PNWH] Pacific Northwest Herbaria, Consortium of. 2015. Herbarium specimen data provided by University of Alaska; University of Idaho; University of Montana; College of Idaho; University of Wyoming; B.A. Bennett Herbarium; United States Forest Service; Idaho State University; University of Lethbridge; Montana State University; Oregon State University; Boise State University; University of Alaska, Anchorage; University of British Columbia; Royal British Columbia Museum; Washington State University; University of Washington. [Accessed 1 January 2015]. http://www.pnwherbaria.org

Pitcairn, M.J., B. Villegas, D.M. Woods, R. Yacoub, AND D.B. JOLEY. 2008. Evaluating implementation success for seven seed head insects on Centaurea solstitialis in California, USA. Pages 610-616 in Proceedings of the XII International Symposium on Biological Control of Weeds. La Grande Motte, Montpellier, France.

Roki, D., N. Menkovic, K. Savikin-Fodulovic, D. KrivoKUCA-Dokic, M. Ristic, AND D. Grubisic. 2001. Flavonoids and essential oil in flower heads of introduced Arnica chamissonis. Journal of Herbs, Spices and Medicinal Plants 8:19-27.

Russo, P., A. Frustaci, A. Del Bufalo, M. Fini, and A. Cesario. 2013. From traditional European medicine to discovery of new drug candidates for the treatment of dementia and Alzheimer's disease: acetylcholinesterase inhibitors. Current Medicinal Chemistry 20:976-983.

SAEED, A. 2014. A pharmacological study of arnica plant. Journal of Functional and Environmental Botany 4:51-54.

Schippmann, U., D.J. Leaman, and A.B. Cunningham. 2002. Impact of cultivation and gathering of medicinal plants on biodiversity: global trends and issues. Pages 1-21 in Biodiversity and the Ecosystem Approach in Agriculture, Forestry and Fisheries. Ninth regular session of the Commission on Genetic Resources for Food and Agriculture. FAO, Rome, Italy.

Shaw, N.L., S.M. Lambert, A.M. DeBolt, and M. Pellant. 2005. Increasing native forb seed supplies for the Great Basin. Pages 94-102 in R.K. Dumroese, L.E. Riley, and T.D. Landis, technical coordinators, National proceedings: Forest and Conservation Nursery Associations, 2004 July 12-15, Charleston, NC; and 2004 July 26-29, Medford, OR. Proceedings RMRS-P-35, USDA Forest Service, Rocky Mountain Research Station, Fort Collins, CO.

Shaw, N., M. Pellant, M. Fisk, and E. Denney. 2012. A collaborative program to provide native plant materials for the Great Basin. Rangelands 34:11-16.
Skuhrovec, J., S. Koprdová, And J. MikulKa. 2008. How can seed feeders regulate dispersion of thistles, Cirsium arvense and C. heterophyllum? Journal of Plant Diseases and Protection 21:277-280.

[SEINet] Southwest Environmental Information Network. 2009-2015. SEINet Arizona-New Mexico Chapter: Welcome to SEINet [landing page]. [Accessed 1 February 2015]. http://swbiodiversity .org/seinet/index.php

Story, J.M., L. Smith, J.G. Corn, And L.J. White. 2008. Influence of seed head-attacking biological control agents on spotted knapweed reproductive potential in western Montana over a 30 -year period. Environmental Entomology 37:510-519.

Sugier, D. 2007. The flowering pattern of Arnica montana L. and A. chamissonis Less. under field cultivation conditions with successive flower head collection. Acta Agrobotanica 60:133-139.

Sugier, D., P. Sugier, And U. Gawlik-Dziki. 2013. Propagation and introduction of Arnica montana L. into cultivation: a step to reduce the pressure on endangered and high-valued medicinal plant species. Scientific World Journal. http://dx.doi.org/10.1155/ 2013/414363

Trock, D.K. 2002. Packera. In: Flora of North America Editorial Committee, editors. 1993+. Flora of North America North of Mexico. 20+ volumes. New York and Oxford. Volume 20, pages 570-602.

Turner, C.E., AND P.B. MCEvoy. 1995. Tansy ragwort Senecio jacobaea L. Asteraceae. Pages 264-269 in J.R. Nechols, L.A. Andres, J.W. Beardsley, R.D. Goeden, and C.G. Jackson, editors, Biological control in the western United States: accomplishments and benefits of Regional Research Project W-84, 1964-1989. Publication No. 3361, University of California, Division of Agriculture and Natural Resources, Oakland, CA.

USDA-NRCS. 2015. The PLANTS Database. National Plant Data Team, Greensboro, NC; [accessed 13 January 2015]. http://plants.usda.gov

Vander Mijnsbrugge, K., A. Bischoff, and B. Smith. 2010. A question of origin: where and how to collect seed for ecological restoration. Basic and Applied Ecology 11:300-311.

Walton, V.M., H.J. Burkack, D.T. Dalton, R. Isaacs, N. Wiman, and C. Ioriatti. 2016. Past, present and future of Drosophila suzukii: distribution, impact and management in United States berry fruits. Acta Horticulturae 1117:87-94.

Wasbauer, M.S. 1972. An annotated host catalog of the fruit flies of America north of Mexico (Diptera: Tephritidae). Occasional Papers Number 19, Bureau of Entomology, California State Department of Agriculture, Sacramento, CA.

Wolf, S.J. 2006. Arnica. In: Flora of North America Editorial Committee, editors. 1993+. Flora of North America North of Mexico. 20+ volumes. New York and Oxford. Volume 21, pages 366-377.

Wolf, S.J., AND T.M. BARKLEy. 2012. Arnica. Pages 246-250 in B.C. Baldwin, D. Goldman, D. Keil, R. Patterson, T. Rosatti, and D. Wilken, editors, The Jepson manual: vascular plants of California. 2nd edition. University of California Press, Berkeley, CA.

Received 17 August 2015

Accepted 25 October 2016

Published online 21 February 2017 